\title{
How to Use Hydrogen in a New Strategy to Mitigate Urban Air Pollution and Preserve Human Health
}

\author{
Louiza Haddad $^{1}$, Zeroual Aouachria ${ }^{2 *}$, Djamel Haddad ${ }^{3}$ \\ ${ }^{1}$ Laboratory of Natural Hazards and Territorial Planning (LARNAT), Univ. Batna2, Batna 05000, Algeria \\ ${ }^{2}$ Applied Energy Physics Laboratory (LPEA), Univ. Batna1, Batna 05000, Algeria \\ ${ }^{3}$ Faculty of engineering, Batna 2, 1 ave. Boukhalouf El hadi, Batna 05000, Algeria
}

Corresponding Author Email: zeroual.aouachria@univ-batna.dz

https://doi.org/10.18280/ijsdp.150705

Received: 7 August 2020

Accepted: 12 October 2020

\section{Keywords:}

urban, air pollution, transportation, renewable energy, fuel cells

\begin{abstract}
If transport is an essential means for the development of the economy, society and its mobility, it has the drawback of leading to significant atmospheric pollution. As traffic density is very high in large cities, air pollution is amplified by the various means of transport resulting from the combustion of fossil fuels. Urban air pollution is mainly caused by vehicles generating emissions harmful to human health. Our objective of this work is to analyze a strategy to eliminate or reduce the emission of these pollutants $\left(\mathrm{NOx}, \mathrm{CO}, \mathrm{CO}_{2}\right)$ during combustion. This strategy aims to explore a clean energy source alternative to fossil fuels. This approach consists of completely replacing the internal combustion scalar with the engine powered by fuel cells using hydrogen. This motivates decision makers to choose hydrogen as an alternative fuel to protect the urban environment and the health human from air pollution. This study shows that it is possible to perfectly mitigate pollutants from urban transport systems by using a PEMFC as an alternative clean energy source. Analyze a strategy to eliminate or reduce the emissions of these pollutants ( $\mathrm{NOx}, \mathrm{CO}, \mathrm{CO}_{2}$ ) during the combustion of full fossil fuel in vehicle engines. This strategy aims to exploit the energy vector represented by hydrogen in order to save human life in more populated areas and protect the environment. The pressure, temperature and concentration of each species $\left(\mathrm{O}_{2}, \mathrm{H}_{2}\right.$ and $\left.\mathrm{H}_{2} \mathrm{O}\right)$ are obtained from the resolution of the electrochemical model coupled to the dynamic model, which we do not present here.
\end{abstract}

\section{INTRODUCTION}

The growing evolution of urbanization requires increasing mobility in conjunction with the expansion of trade, which aims to improve accessibility to different parts of the globe, where it causes inflated traffic. In fact urban air pollution is caused principally by transport systems (vehicles) and less seriously by industrial activities $[1,2]$. In the light of the environment and energy, the development of a sustainable economy is attracting more and more attention worldwide. As a result, many countries have taken specific initiatives to decarbonise their transport sector in particular [2-4]. In summer, the maximum demand for electrical energy in urban areas increases with the increase in temperature. It is evaluated around $2 \%$ for each increase of $0.6^{\circ} \mathrm{C}$ [5]. Raising awareness, sharing information and knowledge between cities around the world, is essential for optimal mitigation of the urban heat island effect [6]. Indeed, combustion of fuel oil generates emissions of gases such as $\mathrm{CO}_{2}, \mathrm{CO}$, Soot, unburned hydrocarbons and even NOx whose rates are often very important. Vehicle emissions, Figure 1, highlights the formation of urban smog and global warming, produced by vehicle emissions [7-9]. The development of a low-carbon economy is increasingly attracting decision-makers in order to protect the environment and save energy. This is why many countries have taken specific initiatives to decarbonise their power generation units and for the transport sectors $[9,10]$. The theoretical laws of stoichiometry's applied to the combustion of hydrocarbons show us that burning one $\mathrm{kg}$ of diesel $(\mathrm{C} 7,25 \mathrm{H} 13)$, gasoline $(\mathrm{C} 7 \mathrm{H} 16)$ or LPG (C3, 5H9) respectively requires $14.6 \mathrm{~kg}, 15.3 \mathrm{~kg}$ or $15.6 \mathrm{~kg}$ of air in order to produce nitrogen $(11.2 \mathrm{~kg}, 11.8 \mathrm{~kg}$ or $12 \mathrm{~kg})$, carbon dioxide $3.2 \mathrm{~kg}, 1.4 \mathrm{~kg}$ or $3.0 \mathrm{~kg}$ ) and water $(102 \mathrm{~kg}, 1.4 \mathrm{~kg}$ or $1.6 \mathrm{~kg})$. These components exist in large quantities in nature, and are chemically stable and essential for the maintenance of natural balances; they are not pollutants but do contribute to the greenhouse effect. But what happens when the laws of stoichiometry are violated? This case can occur when two mixtures (rich and poor) are burnt. In such configuration, one obtains two other products (CO and NO) that are very toxic to living organisms [11]. It has also been found that, whatever the engines, these emissions increase significantly in urban traffic, especially in traffic congestion and also during periods of strong sunshine, Figure 1, [12]. For Diesel we have:

$$
\mathrm{C}_{7.25} \mathrm{H}_{13}+(10.5 \times 3.8) \mathrm{O}_{2} \rightarrow 7.25 \mathrm{CO}_{2}+6.5 \mathrm{H}_{2} \mathrm{O}+4 \mathrm{ON}
$$


It is necessary to develop urban transportation and make real changes in the behaviour of its users. The solution adopted for the reduction of these emissions generally consist of either choosing the most efficient mode of public transport [13] or the use of pre-mixed flames [14-16].

One of the state-of-the-art combustion technologies is combustion without flame which appears to be necessary at this stage as a means for reduction of air pollution [17].

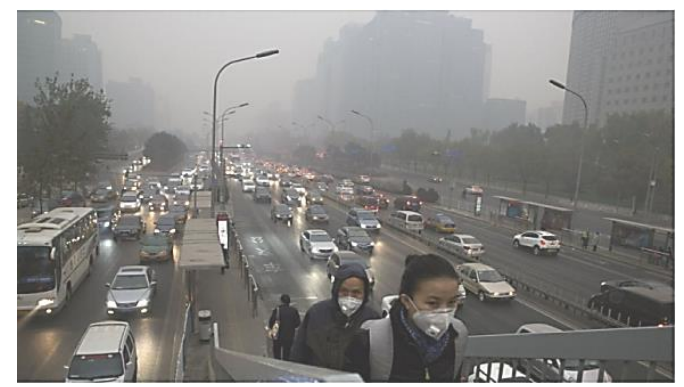

(a)

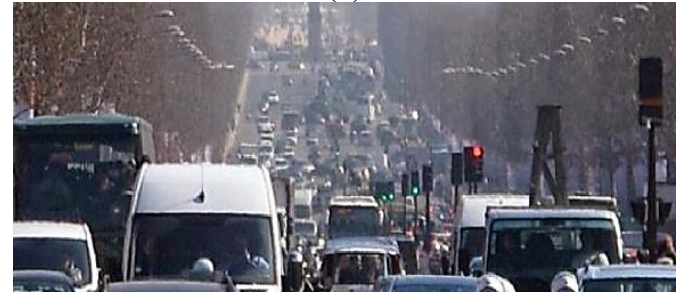

(b)

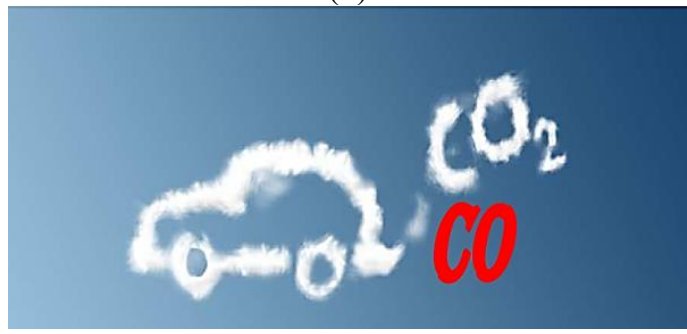

(c)

Figure 1. a) Automobiles play an increasing role in greenhouse effects and air pollution; b) Congestion increases air pollution; c) Non-stoichiometry combustion generates toxic carbon monoxide and carbon dioxide

Several models of turbulence for round jets have been used for the calculation of hydrogen-type diffusion flames. The most common model is the standard $\mathrm{k}-\varepsilon$ with Pope Correction [18], as well as the Realizable k- $\varepsilon$ model [19]. However, the technique of using hydrogen in this way can be dangerous because of its high flammability. In order to avoid this kind of risk, it is recommended to use diffusion flame. Indeed, the efficiency of the results depends both on the choice of turbulence and the chemical kinetics models during combustion. Today, the large deployment of electric vehicles $(\mathrm{EV})$ is one of the main options to reduce environmental pollution. It is clear that electric vehicles (EVs) improve the efficiency of energy conversion and reduces greenhouse emissions by reducing the use of fossil fuels. From 2013 to 2015, EV market share grew significantly in most countries. So if they use low-emission energy sources, the growing number of electric vehicles will undoubtedly benefit the global environment [20-23]. To reach the target of reducing emissions from the urban transport sector by $14 \%$ by 2020 , the British government has supported the testing of electric vehicles, predicting that it plans to play a major role in the future transport sector, especially in urban areas. This type of vehicle will play, not only as a rapid response of the electrical system, but also support, security operations of the electrical system which will represent an alternative energy [24]. Air quality, regarded a main infrastructure element in the urban transportation system, and is considered as major criteria for human settlement. Therefore, transport emitted air pollution appears related to establishment of urban land use in proportion to urban transportation network. Increasing demand for the rest of the total residential areas, along with this development of cities, has given rise to some environmental issues [25-27]. Many studies focus on various models for optimizing electric systems using electric vehicles which have attracted several countries to consider the agent for using this new fuel on a large scale to replace fossil fuels. The USEIA also indicated that around $21 \%$ of world electricity production comes from renewable sources (biofuels, biomass, geothermal energy, hydroelectricity, solar and wind energy in 2011 with a target of $25 \%$ by 2040 ). This situation is illustrated by Figure 2, which shows the net production, of industrial scale installations, from photovoltaic (PV) and wind power.

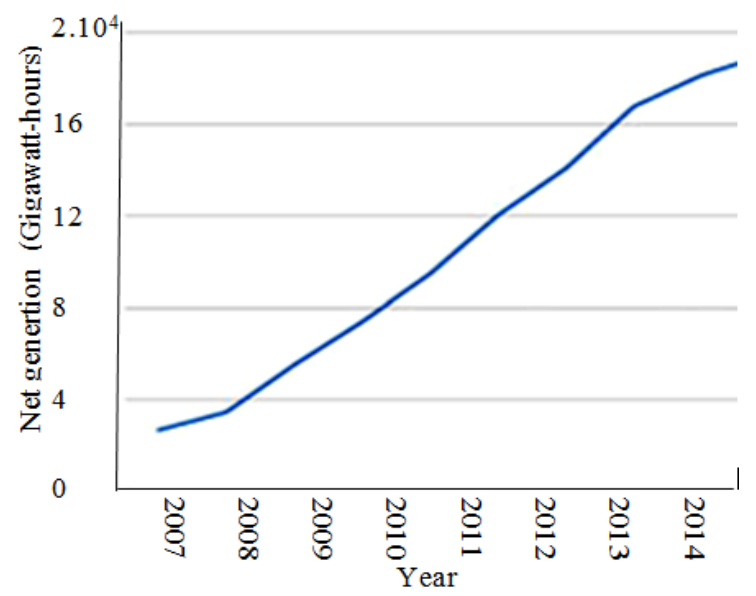

(a)

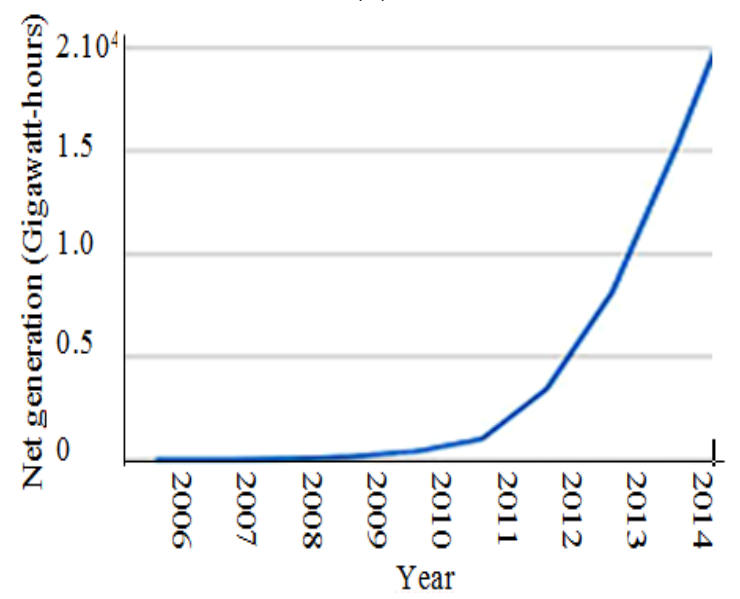

(b)

Figure 2. Net generations in GW-hours at utility scale facilities from -a- solar photovoltaic and -b- wind turbines

From a technological point of view, fuel cells play the role of a generator, which converts electrochemical energy directly into electrical energy. They have many advantages: I- • very good energy efficiency, generally above $50 \%$, depending on the type of fuel cell, II- very little or no pollutant depending on the used fuel, III- soundless, IV-Compactness, for instance fuel cell prototypes may also be used for mobile phones, laptops, etc., V- they can operate at low temperatures $(\approx 20$ - 
$80^{\circ} \mathrm{C}$ ) and require little maintenance. The addition of an electric motor to a conventional combustion engine not only saves energy, but also contributes to the protection of the environment by reducing harmful emissions. Hydrogen fuel cells have the following advantages:

-The ability to provide high current densities compared to reduced operating temperatures,

- Quick Start,

- Immediate response to changes in power demand,

- Emission-free operation [28-34].

Proton exchange membrane fuel cells (PEMFCs) are electro-chemical devices that directly convert chemical energy into electrical one. Such advantages make these cells, particularly suitable for urban transport. It is therefore not surprising to see that all major car manufacturers have their hydrogen vehicle prototype, whether direct combustion (BMW) or fuel cell (GM, PSA, Nissan, Daimler Chrysler, Toyota, Honda, etc.). Worldwide studies predict that two million fuel cell vehicles (buses and individual cars (Figures 3 and 4) will be on the road by 2020 .

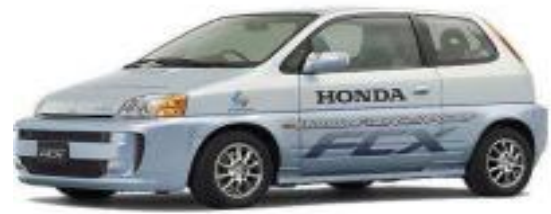

Honda, Juin 2008

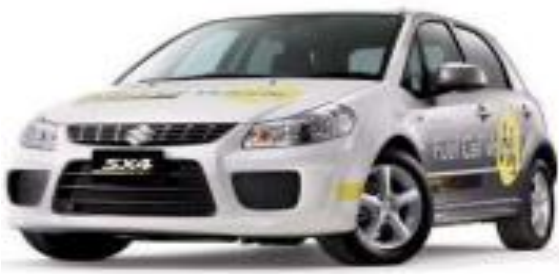

Suzuki SX4FC, Juillet 2008

Figure 3. Véhicules prototypes à pile à combustible

More generally, the enthusiasm for hydrogen is such that numerous structures, bringing together industrial, academic and governmental actors were established as a national and international level [35]. For example, the International Conference on Hydrogen Energy (ICHE),

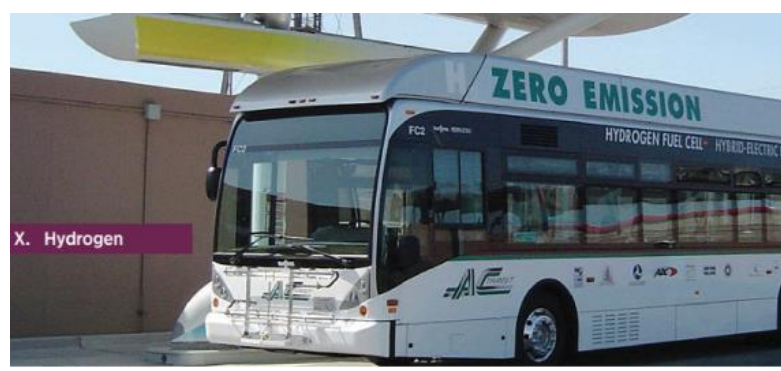

Figure 4. Urban transport system with zero emission: Buses fuel cell in the testing stage

Recent studies on how to adapt batteries for vehicles have shown that a combination of a stoichiometry's factor and a forced draft seems to provide the optimal thermal management strategy of high-temperature PEM fuel cells [36, 37]. One of the most important operational issues for PEMFC that need to be solved is the management of the produced water and heat. Up to now, we have not been able to directly correlate the results of the resistance to mass transfer measured by the impedance channels and by visualization. But it was expected that such a correlation would depend on the transmission line model which is widely debated for the adjustment of low frequencies. A more direct study of the resistance to oxygen diffusion has been felt in works carried out by Coursange [38] and Gilbert [39] who have developed an analytical approach using undersized limiting current measurements and versatile conditions. Since the performance is linked to these two parameters, we propose an idea on how to solve these issues by the processes of heat and mass transport through their membrane [40].

In light of the above, we propose a protection strategy against pollution of the urban environment, based on renewable fuel. To do so, we need to study the performance of a proton exchange membrane fuel cell (PEMFC).

\section{ELECTRIC VEHICLE MODELING}

\subsection{Model description}

The core of the battery consists of an assembly of a proton conducting membrane and two volumetric electrodes. Two electrochemical reactions are carried out on the surface of the electrodes, more precisely at the level of the triple contact Figure 5.

The choice of these batteries (PEMFC) is oriented by their simplicity of design, low operating temperature and high power density. They favour them in several fields of application such as transport. The CFMEP operates at maximum performance at temperatures between 70 and $90^{\circ} \mathrm{C}$. The power range of the applications is still relatively large; 0.1 to $250 \mathrm{KW}$ [41]. A common configuration of fuel cell looks something like that shown in Figure 6 . Figure 6 shows a single cell consisting of two porous electrodes, separated by an electrolyte, through which gas diffuses. The distinction of a battery compared to others is indicated by the choice of electrolyte. The battery electrolyte in Figure 6 consists of a thin membrane capable of conducting only positive ions. Hydrogen is introduced into the cell on one side of the cell while oxygen enters on the opposite side.

Hydrogen is catalytically oxidized to the anode to produce protons as well as electrons, according to an electrochemical reaction. These protons transported from the anode to the cathode through the membrane, and the electrons transmitted through an external electrical circuit will contribute to the reduction of oxygen to produce water, according to an electrochemical reaction. A single cell can generate around $1.23 \mathrm{~V}$ in open circuit and $0.5 \mathrm{~V}$ in normal operation [42]. If we need a higher time it is in the present paper, we propose a model in which the anode-channel feed consists of hydrogen and water vapour, whereas humidified oxygen is fed into the cathode channel. The fuel and oxidant flow rates are governed by a stoichiometric flow where their diffusion takes place in a porous medium constituted by the layers of catalyst and the membrane necessary to mount a number of cells in series.

The diffusion and the catalyst layers with the membrane are porous medium. Hydrogen oxidation and oxygen reduction reactions are considered to occur only within the active catalyst layers which can be described by: 
$2 \mathrm{H}^{2}+2 e^{-}+\frac{1}{2} \mathrm{O}_{2} \rightarrow \mathrm{H}_{2} \mathrm{O}$ and $\mathrm{H}_{2} \rightarrow 2 \mathrm{H}^{+}+2 e^{-}$

This can be summarized as:

$2 \mathrm{H}^{2}+2 e^{-}+\frac{1}{2} \mathrm{O}_{2} \rightarrow \mathrm{H}_{2} \mathrm{O}+$ heat + electrical energy

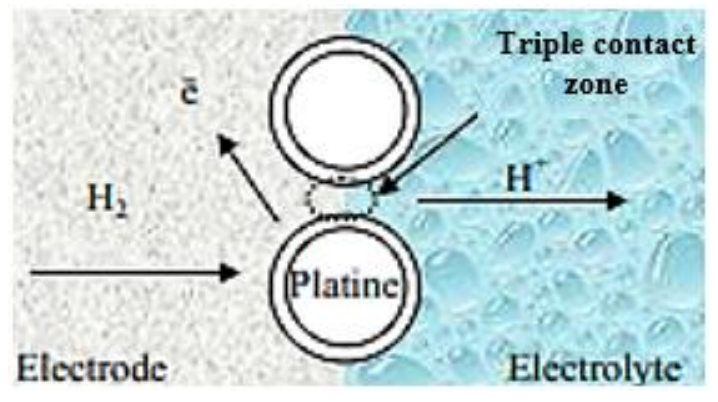

Figure 5. The triple contact representation area [41]

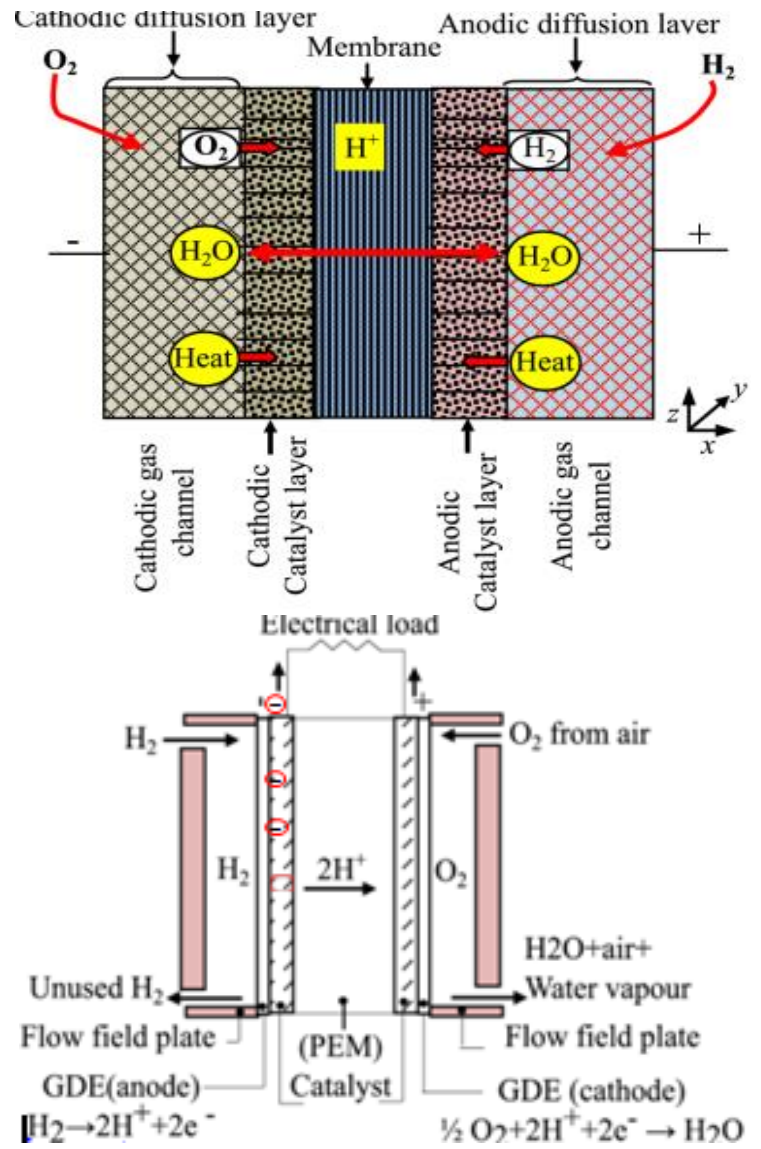

(a) elements fitting pattern $f$ of a PEMFC explaining the capillary force drawing the gas at the inlet and reject water outlet in the GD

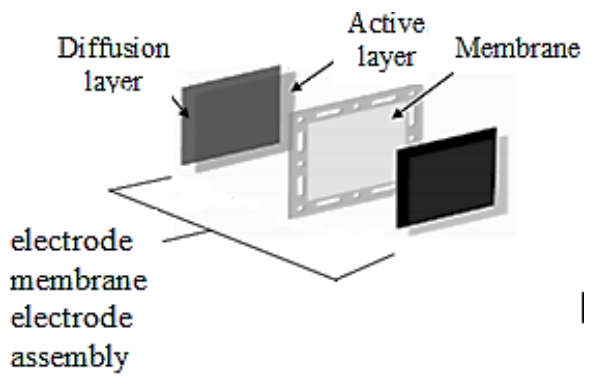

(b) Schematic representation of the electrode membrane electrode assembly

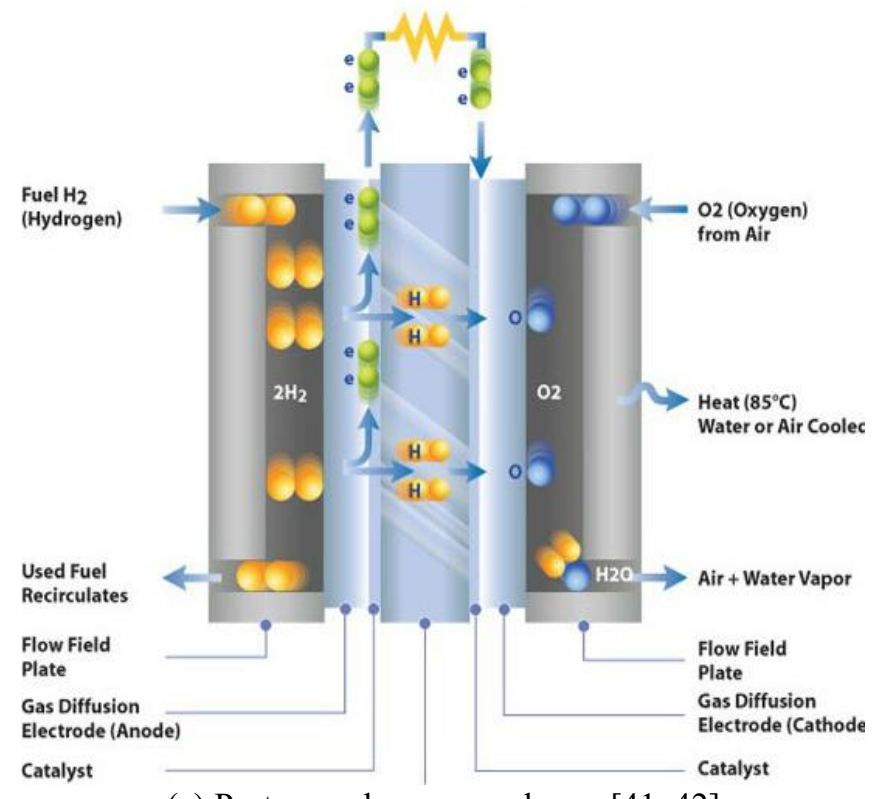

(c) Proton exchange membrane [41, 42]

Figure 6. Basic configuration of a PEMFC

The gas-liquid interface moves from the catalyst layer to the diffusion layer as the relative humidity of the cathode increases. When the relative humidity of the cathode reaches $100 \%$, the gas-liquid interface is close to the inlet of the gas flow channel. The relative humidity of the cathode increases when the condensed water in the pores of the porous medium blocks the transport of the combustible. This causes the performance of the cell and the power density to decrease. Reducing the operating voltage of the cell reduces the distance between the gas-liquid interface and the inlet of the gas flow channel due to the high currents generated by large electrochemical reactions. We are also witnessing the decrease in oxygen and the increase in the fraction of water. The transport of liquid water through the porous medium is driven by the shearing in the channel and by the capillary forces for this liquid water moves from the catalyst layer to the gas diffusion layer [41, 42]. An ideal GDL must possess a number of characteristics such as an efficient transport of gaseous reactants to the catalyst layers, a good hydrophobicity and low electron resistivity. It also plays a crucial role in the removal of water (by-product of the chemical reaction) from the anode.

\subsection{Problem formulation}

In this model and for brevity, we do not present the mathematical transport equations, the source terms and the closest relations (it is similar to the above problem). Energy is transported by conduction and convection in the three phases (polymer, liquid, gas) of the fuel cell fig.6. In order not to overload the text, the analysis of the dynamics, widely used in the literature, will be omitted in this study. Energy is transferred in the liquid, solid and gas phases which are revealed in the different parts of the cell (Figure 6), by the modes of conduction and convection. Ohmic polarization and activation effects in the membrane and in the catalyst layers are taken into account in the source term of the energy equation [43].

$$
\frac{\partial T}{\partial t}+\sum_{k=1}^{N} U_{k} \frac{\partial T}{\partial x_{k}}=\sum_{k=1}^{N} \frac{\partial}{\partial x_{k}}\left[\alpha_{\lambda}^{e f f} \frac{\partial T}{\partial x_{k}}\right]+S_{T}
$$


The governing equations of the thermo-chemical problem can be written as follows:

$$
S_{T}=\frac{\left(\eta_{o m h}+\eta_{a c t}\right) \cdot i}{\left(\rho \cdot C_{p}\right)^{e f t}}
$$

In electrochemistry, the Nernst equation gives the thermodynamic equilibrium potential (Nernst) of the electrode relative to the standard potential (E0) of the redox pair involved. It can be written as follows:

$$
E_{\text {Nernest }}=10^{-5} T\left[4.31\left(\ln P_{a}^{*}+\frac{1}{2} \ln P_{c}^{*}\right]+0.9755\right.
$$

In cell operation, the potential of the cell is lower than its thermodynamic equilibrium potential because of the irreversible differences in losses that must be taken into account in the numerical simulation $[44,45]$.

$$
V_{\text {cell }}=E_{\text {Nersst }}-\eta_{\text {act }}-\eta_{\text {omh }}-\eta_{\text {conc }}
$$

The Ohmic losses in the electrolyte are calculated using Ohm's law [46]:

$$
\eta_{o m h}=\frac{i}{\sigma_{m}}
$$

The proton conductivity in the membrane phase was correlated by Boulanger et al. [4], through the equation:

$$
\sigma_{m}=(0.5139 \gamma-0.326) \cdot \exp \left(1268 \cdot\left(\frac{1}{303}-\frac{1}{T}\right)\right)
$$

The water content in the membrane $\mathrm{H}_{2} \mathrm{O} / \mathrm{SO}_{2}, \boldsymbol{\gamma}_{\mathbf{H}_{\mathbf{2}} \boldsymbol{O} / \boldsymbol{S O}_{2}}$ depends on the molar concentration of water $\mathrm{C}_{\mathrm{H}_{2} \mathrm{O}}^{m}$ and the activation polarization are considered from the literature [47]

$$
\gamma_{\mathrm{H}_{2} \mathrm{O} / \mathrm{SO}_{3}^{-}}=\frac{C_{\mathrm{H}_{2} \mathrm{O}}^{m}}{\frac{\rho_{\mathrm{Sec}}^{m}}{M^{m}-0.025 C_{\mathrm{H}_{2} \mathrm{O}}^{m}}}
$$

where, $M^{m}$ is the molecular coefficient of the membrane and $\rho_{s e c}^{m}$ is the density of the dry membrane. The activation polarization is given by $[48,49]$

$$
\eta_{a c t}=\left[\xi_{1}+\xi_{2} \cdot T+\xi_{3} \cdot T \cdot \ln \left(C_{o_{2}}\right)+\xi_{4} \cdot T \cdot \ln (i)\right]
$$

where, $i$ is the current density, $\mathrm{CO}_{2}$ is the oxygen concentration at the cathode catalytic interface, is the hydrogen concentration at the anode catalytic interface, and $\xi_{1}, \xi_{2}, \xi_{3}$ and $\xi_{4}$ are the parametric coefficients for each fuel cell model:

$$
\begin{gathered}
\xi_{1}=-0.948 \\
\xi_{2}=\left[283+\ln \left(A^{20}+C_{H 2}^{4.3}\right)\right] \cdot 10^{-5} \\
\xi_{3}=7.6 .10^{-5} \\
\xi_{4}=-1.93 .10^{-4}
\end{gathered}
$$

In Eq. (7), $\eta_{\text {conc }}$ is the concentration polarization of the overpotential:

$$
\eta_{\text {conc }}=-\frac{R \cdot T}{2 \cdot F} \ln \left(1-\frac{i}{i_{\max }}\right)
$$

The pressure, temperature and concentration of each species (oxygen, hydrogen and water) are obtained from the resolution of the dynamic model coupled to the electrochemical model, which we do not present here.

\section{MODEL VALIDATION}

We note that at present, the polarization curve is the only experimental data available in the literature, polarization curves are therefore commonly used to validate the agreement between the digital model and the experiments. Figure 7 gathers the results obtained by the present model and that obtained experimentally by Cheng [50] at a temperature $\mathrm{T}=$ $353.15 \mathrm{~K}$. The curve of polarization versus current density for the average model agrees well with that of Cheng.

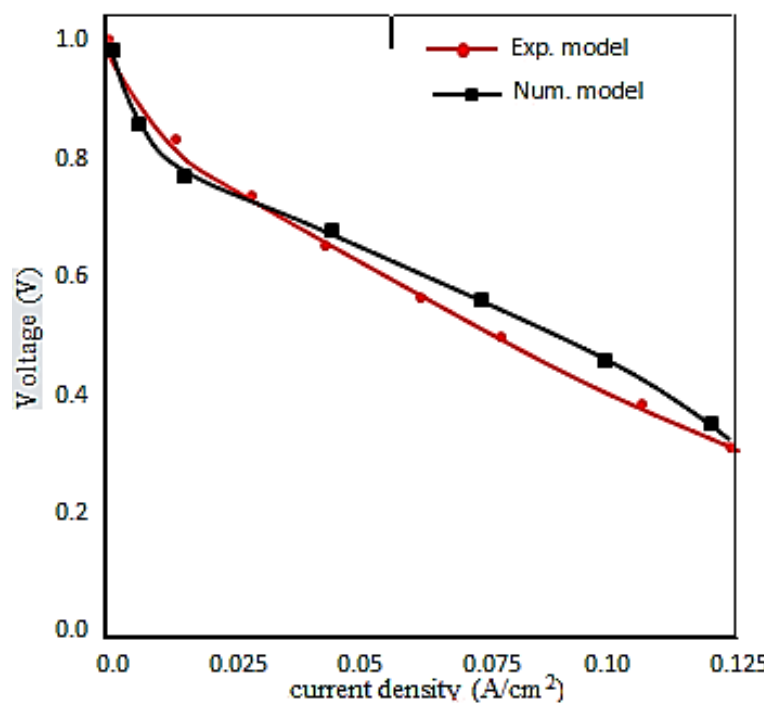

Figure 7. Comparison of the predicted performance curves with the experimental data of Cheng [50]

\section{RESULTS AND DISCUSSION}

In the Fuel cells, for urban transport, the influence of the flow and the electrochemical reaction on the concentration distribution of reactants $\left(\mathrm{O}_{2}, \mathrm{H}_{2}\right)$, production $\left(\mathrm{H}_{2} \mathrm{O}\right)$ and on the temperature in all parts of the fuel cell shows that there are two important regions to consider. The first region has the thermal and mass boundary layers along the canal, see Figure 4 . We observe that the increase in thickness of the boundary layers of the reactants is more nuanced than that of water and temperature. The second region (membrane electrode assembly (MEA) presents the electrochemical reaction and the porous medium effect. The results show that the mass and heat diffusion in the porous medium is slowed down because of the permeability effect. This influences the performance of the hydrogen fuel cell. 


\subsection{Temperature effect on the polarisation curve}

The polarization curve of the cells, at normal operating temperature and humidity, is illustrated in Figure 8. Low and high operating temperatures limit the cell performance. In fact, the potential of the cell decreases significantly with respect to the optimum operating temperature $(353 \mathrm{~K})$ between $333 \mathrm{~K}$ and $343 \mathrm{~K}$, as the resistive losses in the membrane increase. The improvement of the cell potential, generated by the operating temperature, can be explained by the reduction of losses in the cell and of the iconic conductivity which results from a lower resistive loss in the membrane. Although the extent of the operating temperature reduces Ohmic losses, transport and activation, at temperatures $353 \mathrm{~K}$ and $363 \mathrm{~K}$, Figure 8 , the cell potential decreases due to an increase in partial pressure. In addition, an excessive operating temperature may lead to dehydration causing a drop of ionic conductivity, which could result in excessive thermal stress and cause a rupture of the membrane. The electrolyte potential improves when the input flow is well humidified and the membrane is well dehydrated. Therefore, temperature can have a positive effect on oxygen reduction, but resistance to protons is higher. Saying then that the dehydration of electrolytes has a dominant influence on the reduction of the cathodic reaction

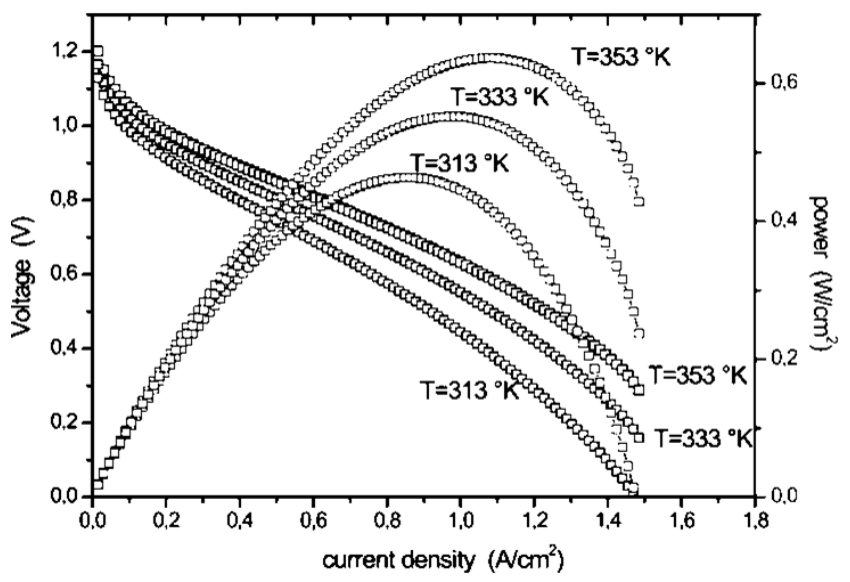

Figure 8. Temperature effect on the Cell polarization curves

\subsection{Humidity effect on the cell polarisation curve}

Note in Figure 9 that the reduction of Ohmic losses along with increasing relative humidity improves the potential of the cell. However the effect of relative humidity in the range $(100 \%-110 \%)$ on this potential is not significant cell potential for the relative humidity from $100 \%$ to $110 \%$. This agrees with the fact that the excess water from its condensation, in the vicinity of the anode and the actual concentration of water vapor in the anode catalyst layer, did not exceed $100 \%$. The dry input flows increase the electrolyte voltage losses. This will negatively affect the rate of reaction at the cathode level by reducing the conductivity of the protons in the polymer electrolyte. In fact, this depends linearly on the water contained therein. At low current densities, where joule heating and reaction heat are low, the condensation of water in the cell has a considerable impact involving the preponderance of latent heat.

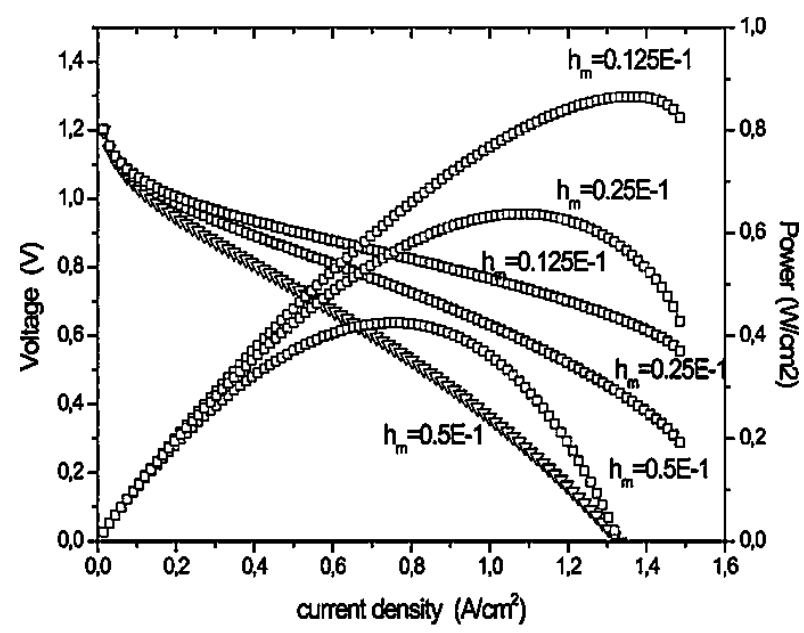

Figure 9. Humidity effect on the Cell polarization curves

\subsection{Pressure effect on the Cell polarization curves}

The same effect is observed in the case of the pressure on the characteristic of polarization of the cell. Indeed, we can read on Figure 10 that for the pressure of 5 bars, the characteristic parameters of the cell are very close to those corresponding to $353 \mathrm{k}\left(\mathrm{I}=1.1 \mathrm{~A} / \mathrm{cm}^{2}, \mathrm{~V}=1.18 \mathrm{~V}\right.$ and $\mathrm{P}=$ $\left.0.64 \mathrm{~W} / \mathrm{cm}^{2}\right)$.

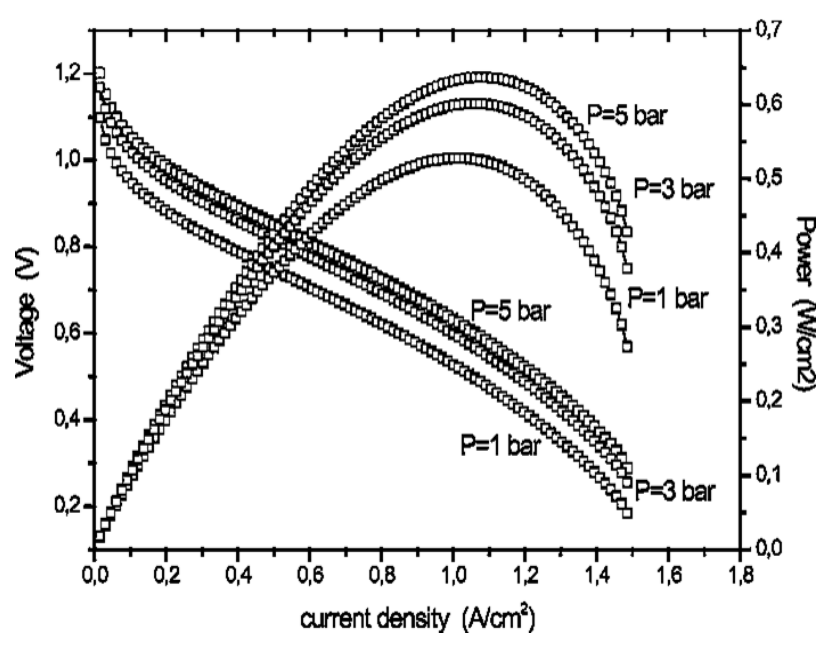

Figure 10. Pressure effect on the Cell polarization curves

\subsection{Conductivity effect on the Cell polarization curves}

Figure 10 Evolution of the voltage and power as current density functional for different conductivity and humidity. It shows the voltage and power as functions of the current density for different conductivity. On this polarization curve, obtained thanks to a digital simulation, a significant decrease in voltage and power density is observed with the increase in current. This results from the different types of losses in the cell. The power reaches its maximum an optimal current of $0.64 \mathrm{~W} / \mathrm{m}^{2}$ (for $1.1 \mathrm{~A} / \mathrm{m}^{2}, \mathrm{U}=1.28 \mathrm{~V}$ and $\mathrm{l}=14 \mathrm{~W} / / \mathrm{m}^{2}$ ) Figure 9 and $0.875 \mathrm{~W} / \mathrm{m}^{2}\left(\mathrm{I}=1.4 \mathrm{~A} / \mathrm{m}^{2}, \mathrm{U}=1.3 \mathrm{~V}\right.$ and $\left.\mathrm{hm}=0.1251061\right)$ Figure 11. For automotive traction, only PEMFCs can contribute to the protection against air pollution in urban spaces in a very efficient way. 


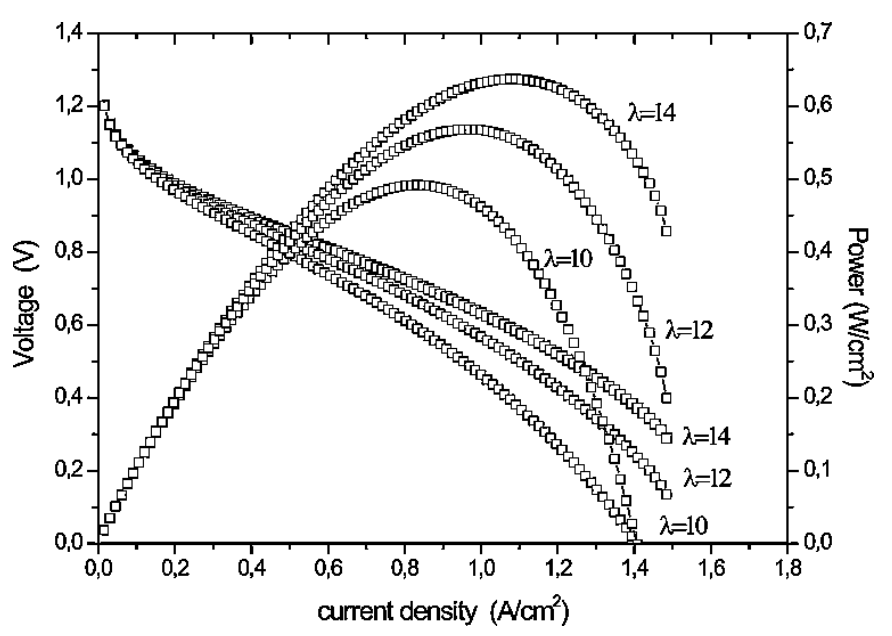

Figure 11. Conductivity effect on the cell polarization curves

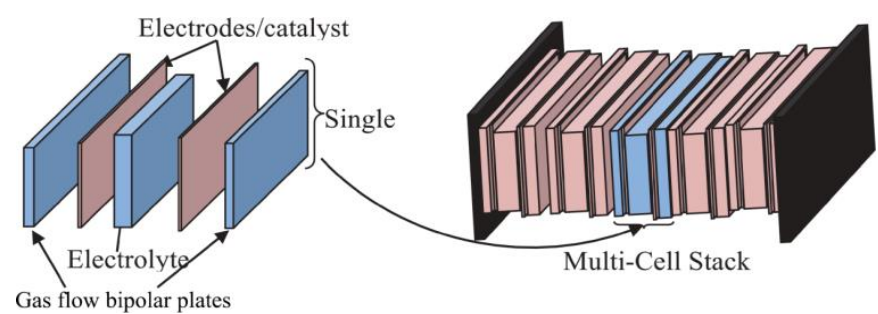

(a) Detailed structure of a cell

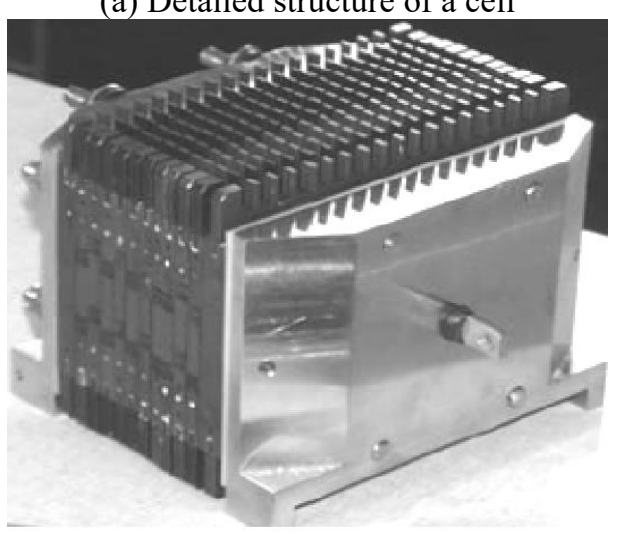

(b) Hydrogen battery

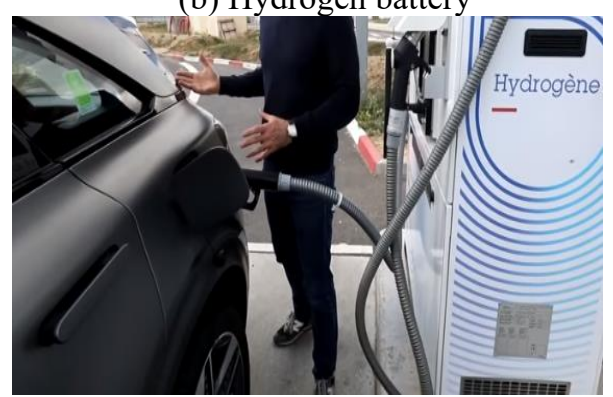

(c) charge station

Figure 12. A multi-cell stacks made up of multiple cells to increase the voltage

\subsection{How to profit from these techniques results}

At the environmental level, the noise pollution is also very low since the applications envisaged do not have moving parts. It should also be noted that the reaction products of the batteries are non-polluting and therefore harmful gas emissions from the battery alone are essentially zero. The assembly techniques, which are particularly suited to PEMFCs, are in principle simple and offer a wide range of applications from $1 \mathrm{~W}$, for small applications, up to several hundred $\mathrm{kW}$ for large applications. One can classify the fields of application into three categories: stationary, automotive and portable. In the automotive case, the battery of a car must consist of a number of cell units, placed in series as shown in Figure 12, so that their useful power is equal to that of the battery.

\section{CONCLUSION}

The model discussed in this paper illustrates several important phenomena in the cell and allows a detailed analysis of each component. The main noticed and concluded effects are:

-The increase in current density leads to an increase in water transfer, thus increasing the drying of the membrane.

-Applying a pressure gradient in the opposite direction of water flow and/or feeding the cell with moister hydrogen leads to compensation for this dehydration.

- The contribution of water convective and migration are intensive compared to the water diffusion.

- The number of cells required for a battery used for a 6-ch car is 85 cells, the size of which does not exceed that of two conventional batteries.

-In addition, the modelling of electrochemical kinetics and electrical conduction. PEMFC fuel cells allow us to operate and improve existing models. With the optimization and validation of concepts according to various approaches in. optimal operating conditions for these fuel cells. This motivates decision makers to choose hydrogen as an alternative fuel to protect the urban environment and the health human from air pollution.

In perspective, the study is in progress to establish an optimization of energy management in a fuel cell electric vehicle to improve its performance in terms of acceleration and long life of the fuel cell.

\section{REFERENCES}

[1] Haddad, L., Haddad, D., Aouachria, Z. (2016). Noise pollution analyses in urban cites: Batna city case. International Journal for Traffic and Transport Engineering, $\quad 6(3)$ : 253-264. https://dx.doi.org/10.7708/ijtte.20.6(3).02

[2] Sefair, J.A., Espinosa, M., Behrentz, E., Medaglia, A.L. (2019). Optimization model for urban air quality policy design: A case study in Latin America. Computers, Environment and Urban Systems, 78: 101385. https://doi.org/10.1016/j.compenvurbsys.2019.101385

[3] Parkinson, S., Wang, D., Djilali, N. (2012). Toward low carbon energy systems: The convergence of wind power, demand response, and the electricity grid. IEEE PES Innovative Smart Grid Technologies, Tianjin, China, pp. 1-8. https://doi.org/10.1109/ISGT-Asia.2012.6303401

[4] Boulanger, A.G., Chu, A.C., Max, S., Waltz, D. (2014). Vehicle electrification: Status and issues. Proceedings of the IEEE, 99(6): 1116-1138. https://doi.org/10.1109/JPROC.2011.2112750

[5] Mohajerani, A., Bakaric, J., Jeffrey-Bailey, T. (2015). The urban heat island effect, its causes, and mitigation, with reference to the thermal properties of asphalt concrete. Journal of Environmental Management, 197: 522-538. https://doi.org/10.1016/j.jenvman.2017.03.095 
[6] Wang, G.J., Macera, C.A., Scudder-Souci, B., Schmidt T., Pratt, M., Buchner, D. (2004). Cost analysis of the built environment: the case of bike and pedestrian trails in Lincoln Neb. American Journal of Public Health, 94(4): 549-553. https://doi.org/10.2105/ajph.94.4.549

[7] Younger, M., Morrow, A., Lmeida, H.R., Vindigni, S.M., Dannenberg, A.L. (2008). Built environment, climate change and health: Opportunities for co-benefits. American Journal of Preventive Medicine, 35(5): 517526. http//dx.doi.org/10.1016/j.amepre.2008.08.017

[8] Hadef, A., Aouachria, Z. (2014). The interactions of the kinetic chemistry and the turbulence on the turbulent diffusion flame. AIP Proceedings, 1557: 174-179. http//dx.doi.org/10.1063/1.4823898

[9] Doolan, R., Muntean, G.M. (2014). Reducing carbon emissions by introducing electric vehicle enhanced dedicated bus lanes. 2014 IEEE Intelligent Vehicles Symposium Proceedings, Dearborn, MI, USA. http//dx.doi.org/10.1109/IVS.2014.6856418

[10] Yang, J.Y., Shi, B.X., Zheng, Y., Shi, Y., Xia, G.Y. (2020). Urban form and air pollution disperse: Key indexes and mitigation strategies. Sustainable Cities and Society, $\quad 57$ : 101955 http//dx.doi.org/10.1016/j.scs.2019.101955

[11] Haider, T., Ronnen, L., Arash, M., Haley, G., George, B.W., Sharon, C. (2018). Air-temperature response to neighborhood-scale variations in albedo and canopy cover in the real world: Fine-resolution meteorological modelling and mobile temperature observations in the Los Angeles climate archipelago. Climate, 6(2): 53. https://doi.org/10.3390/cli6020053

[12] Ranga Dinesh, K.K.J., Luo, K.H., Kirkpatrick, M.P., Malalasekera, W. (2013). Burning syngas in a high swirl burner: Effects of fuel composition. International Journal of Hydrogen Energy, 38(21): 9028-9042. https://doi.org/10.1016/j.ijhydene.2013.05.021

[13] Zouagri, R., Mameri, A., Fouzi, T. (2017). Characterization of the combustion of the mixture Biogas-Syngas Part I: Effect of the mixture composition and radiation. Fuel, 271: 117580. https://doi.org/10.1016/j.fuel.2020.117580

[14] Mei, Z., Li, P., Mi, J., Wang, F., Zhang, J. (2015). Diffusion MILD combustion of firing pulverized-coal at a pilot furnace. Flow Turbulence Combustion, 95: 803829. https://doi.org/10.1007/s10494-015-9642-0

[15] Merotto, L., Sirignano, M., Commodo, M., D’Anna, A., Dondè, R., Iuliis. S.D. (2017). Experimental characterization and modelling for equivalence ratio sensing in non-premixed flames using chemiluminescence and laser-induced breakdown spectroscopy techniques. Energy Fuels, 31(3): 32273233. https://doi.org/10.1021/acs.energyfuels.6b03094

[16] Fang, Y., Zou, R., Luo, G., Chen, J., Li, W., Mao, W., Zhu, X., Peng, F., Guo, S., Li, X., Yao, H. (2017). Kinetic study on coal char combustion in a micro fluidized bed. Energy \& Fuels, 31(3): 3243-3252. https://doi.org/10.1021/acs.energyfuels.6b03137

[17] Pope, S.B. (1978). An explanation of the turbulent round jet/plane jet anomaly. AIAA Journal Tech. Notes, 16(3): 279-281. https://doi.org/10.2514/3.7521

[18] Pope, S.B. (1994). Lagrangian PDF methods for turbulent flows. Annual Review of Fluid Mechanics, 26: 23-63.

https://doi.org/10.1146/annurev.fl.26.010194.000323
[19] Poinsot, T., Veynante, D. (2017). Theoretical and Numerical Combustion, 2nd ed. Publisher: R.T. Edwards, 220-225.

[20] Katsuki, M., Hasegawa, T. (1998). The science and technology of combustion in highly preheated air. Symposium (International) on Combustion, 27(2): 31353146. https://doi.org/10.1016/S0082-0784(98)80176-8

[21] Liu, C., Chau, K.T., Wu, D., Gao, S. (2013). Opportunities and challenges of vehicle-to-home, vehicle-to-vehicle, and vehicle-to-grid technologies. Proceedings of the IEEE, 101(11): 2409-2427. https://doi.org/10.1109/JPROC.2013.2271951

[22] Chan, C.C. (2007). The state of the art of electric, hybrid, and fuel cell vehicles. Proceedings of the IEEE, 95(4): 704-718. https://doi.org/10.1109/JPROC.2007.892489

[23] Cobb, J. (2015). Top 6 plug-in vehicle adopting countries. www.hybridcars.com/top-6-plug-in-vehicle.

[24] Wen, Z., Liu, J., Liu, Y., Chen, B., Liu, A. (2017). The effect of hydrogen addition on the combustion characteristics of RP-3 kerosene/air premixed flames. Energies, $10(8)$ :

1107. https://doi.org/10.3390/en10081107

[25] Ranjan, K. (2001). Development of spatial and attribute database for planning and managing rural service centers in Kendrapara district, Orissa, India: A GIS based information. Journal of Applied Gerontology, 3(1): 99105.

[26] Hadipour, M., Pourebrahim, S., Mahmmu, A.R. (2009). Mathematical modeling considering air pollution of transportation: An urban environmental planning, case study in petaling jaya, Malaysia. Theoretical and Empirical Researches in Urban Management Number 4(13): 75-92.

[27] Squilbin, D.V. (2015). Directives de la qualité de l'air de l'organisation mondiale de la santé, Bruxelles environnement, collection fiches documentées, thématique air. www.anses.fr.

[28] Zhang, H., Yue, G., Lu, J., Jia, Z., Mao, J., Fujimori, T., Suko, T., Kiga, T. (2007). Development of high temperature air combustion technology in pulverized fossil fuel fired boilers. Proceedings of Combustion Institute, $\quad 31(2)$ : 2779-2785. https://doi.org/10.1016/j.proci.2006.07.135

[29] Rathnam, R.K., Elliott, L.K., Wall, T.F., Liu, Y., Moghtaderi, B. (2009). Differences in reactivity of pulverised coal in air $\left(\mathrm{O}_{2} / \mathrm{N}_{2}\right)$ and oxy-fuel $\left(\mathrm{O}_{2} / \mathrm{CO}_{2}\right)$ conditions. Fuel Process Technology, 90(6): 797-802. https://doi.org/10.1016/j.fuproc.2009.02.009

[30] EIA, Electric Power Monthly. (2016). Table 1.1.A. Net generation from renewable sources: total (all sectors), January, EIA US. www.eia.gov, accessed on May 12, 2020.

[31] Edwards, P.P., Kuwnetson, V.L., David, Z.I.F. (2007). Hydrogen energy. Philosophical Transactions of the Royal Society of London A, 365(1853): 1043-1056. https://doi.org/10.1098/rsta.2006.1965

[32] Owejan, J.P., Trabold, T.A., Mench, M.M. (2014). Oxygen transport resistance correlated to liquid water saturation in the gas diffusion layer of PEM fuel cells. International Journal of Heat and Mass Transfer, 71: 585592.

https://doi.org/10.1016/j.ijheatmasstransfer.2013.12.059

[33] Naterer, G.F., Suppiah, S., Stolberg, L., Lewis, M., Ferrandon, M., Wang, Z., Dincer, I., Gabriel, K., Rosen, 
M.A., Secnik, E., Easton, E.B., Trevani, L., Pioro, I. Tremaine, P., Lvov, S., Jiang, J., Rizvi, G., Ikeda, B.M., Avsec, J. (2011). Clean hydrogen production with the $\mathrm{Cu}-\mathrm{Cl}$ cycle - Progress of int. consortium, I: Experimental unit operations. International Journal of Hydrogen Energy, 36(24): 15472-15485. https://doi.org/10.1016/j.ijhydene.2011.08.012

[34] Sun, Y., Wang, G., Yan, K. (2011). $\mathrm{TiO}_{2}$ nanotubes for hydrogen generation by photocatalytic water splitting in a two-compartment photo-electrochemical cell. International Journal of Hydrogen Energy, 36(24): 15502-15508. https://doi.org/10.1016/j.ijhydene.2011.08.112

[35] Ilie, M., Cojocaru, B., Parvulescu, V.I., Garcia, H. (2011). Improving $\mathrm{TiO}_{2}$ activity in photo-production of hydrogen from sugar industry wastewaters. International Journal of Hydrogen Energy, 36(24): 15509-15518. https://doi.org/10.1016/j.ijhydene.2011.09.029

[36] Caulk, D.A., Baker, D.R. (2010). Heat and water transport in hydrophobic diffusion media of PEM fuel cells. Journal of the Electrochemical, Society, 157(8): 1237-1244.

[37] Mondal, B., Chatterjee, D. (2016). Numerical investigation of the water droplet transport in a PEM fuel cell with serpentine flow channel. Journal of Applied Fluid Mechanics, 9(3): 1057-1071. https://doi.org/10.18869/acadpub.jafm.68.228.24144

[38] Coursange J.F. (2003). Modélisation de Pile à Combustible à Membrane de Polymère en $3 \mathrm{D}$, Thèse de doctorat Université du Québec à Trois-Rivières. www.uqtr.ca/STI.

[39] Gilbert, M. (2004). Renewable and Efficient Electric Power Systems. Hoboken, New Jersey, by John Wiley \& Sons.

[40] Feng, Z., Virkar, A.V. (2005). Dependence of polarization in anode-supported solid oxide fuel cells on various cell parameters. Journal of Power Sources, 141(1): 79-95. https://doi.org/10.1016/j.jpowsour.2004.08.057

[41] Baumgartner, W.R., Parz, P., Fraser, S.D., Wallnofer, E., Hacker, V. (2008). Polarization study of a PEMFC with four reference electrodes at hydrogen starvation conditions. Journal of Power Sources, 182(2): 413-421. https://doi.org/10.1016/j.jpowsour.2008.01.001

[42] Yang, D., Li, B., Zhang, H., Zheng, J., Lin, R., Ma, J. (2012). The application of $\mathrm{Ir}-\mathrm{V} / \mathrm{C}$ catalyst as a durable anode catalyst for a $1.5 \mathrm{~kW}$ proton exchange membrane fuel cell stack. Journal of Power Sources, 199: 68-74. https://doi.org/10.1016/j.jpowsour.2011.10.035

[43] Phong, L.H., Van, D.T.B., Bao, H.H.G. (2018). The role of globalization on $\mathrm{CO}_{2}$ emission in Vietnam incorporating industrialization, urbanization, GDP percapita and energy use. International Journal of Energy Economics and Policy, 8(6): 275-283. https://doi.org/10.32479/ijeep.7065

[44] Al-Baghdadi Sadiq, M.A.R. (2005). Modelling of proton exchange membrane fuel cell performance based on semi-empirical equations. Renewable Energy, 30(10): 1587-1599.

https://doi.org/10.1016/j.renene.2004.11.015

[45] Bernardino, D.M., Verbrugge, M.W. (1992). A mathematical model of the solid-polymer-electrolyte fuel cell. J. Electrochem Soc., 139(9): 2477-2491.

[46] Lu, Z.J., Daino, M.M., Rath, C., Kandlikar, S.G. (2010). Water management studies in PEM fuel cells, part III: dynamic breakthrough and inter mitten drainage characteristics from GDLs with and without MPLs. International Journal of Hydrogen Energy, 35(9): 42224233. https://doi.org/10.1016/j.ijhydene.2010.01.012

[47] Eikerling, M., Kornyshev, A.A. (1998). Modelling the performance of the cathode catalyst layer of polymer electrolyte fuel cells. Journal of Electrochemical Society, 453(1-2): 89-106. https://doi.org/10.1016/S00220728(98)00214-9

[48] Fuller, T.F., Newman, J. (1993). Water and thermal, management in solid-polymer-electrolyte fuel cells. Journal of Electrochemical Society, 140(5): 1218-1224.

[49] Nguyen, T.V., White, R.E. (1993). A water and heat management model for proton-exchange-membrane fuel cells. Journal of Electrochemical Society, 140(8): 21782186. https://doi.org/10.1149/1.2220792

[50] Cheng, B., Ouyang, M.G., Yi, B.L. (2006). Analysis of water management in proton exchange membrane fuel cells. Tsinghus Science Technology, 11(1): 54-64. https://doi.org/10.1016/S1007-0214(06)70155-9 